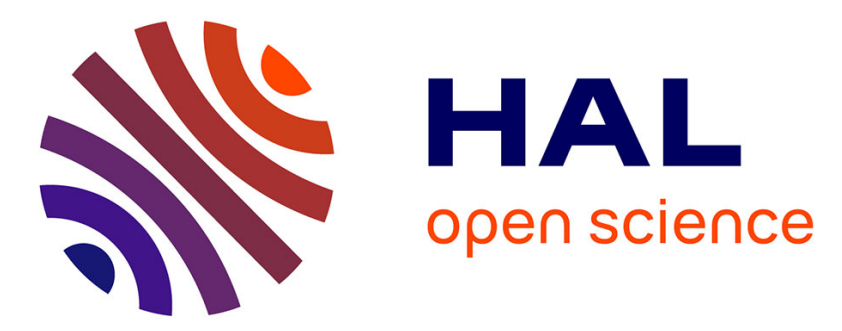

\title{
Collaborative Networks as a Core Enabler of Industry
} 4.0

Luis M. Camarinha-Matos, Rosanna Fornasiero, Hamideh Afsarmanesh

\section{To cite this version:}

Luis M. Camarinha-Matos, Rosanna Fornasiero, Hamideh Afsarmanesh. Collaborative Networks as a Core Enabler of Industry 4.0. 18th Working Conference on Virtual Enterprises (PROVE), Sep 2017, Vicenza, Italy. pp.3-17, 10.1007/978-3-319-65151-4_1 . hal-01674850

\section{HAL Id: hal-01674850 https://hal.inria.fr/hal-01674850}

Submitted on 3 Jan 2018

HAL is a multi-disciplinary open access archive for the deposit and dissemination of scientific research documents, whether they are published or not. The documents may come from teaching and research institutions in France or abroad, or from public or private research centers.
L'archive ouverte pluridisciplinaire HAL, est destinée au dépôt et à la diffusion de documents scientifiques de niveau recherche, publiés ou non, émanant des établissements d'enseignement et de recherche français ou étrangers, des laboratoires publics ou privés.

\section{(c)(1)}

Distributed under a Creative Commons Attribution| 4.0 International License 


\title{
Collaborative Networks as a Core Enabler of Industry 4.0
}

\author{
Luis M. Camarinha-Matos ${ }^{1}$, Rosanna Fornasiero ${ }^{2}$, Hamideh Afsarmanesh ${ }^{3}$ \\ ${ }^{1}$ Nova University of Lisbon, Faculty of Sciences and technology \& Uninova - CTS, \\ Campus de Caparica, Portugal, cam@uninova.pt \\ ${ }^{2}$ ITIA-CNR, Vicenza, Italy, rosanna.fornasiero@itia.cnr.it \\ ${ }^{3}$ University of Asmterdam, Informatics Institute, Amsterdam, Netherlands, \\ h.afsarmanesh@uva.nl
}

\begin{abstract}
The notion of Industry 4.0 is having a catalyzing effect for the integration of diverse new technologies towards a new generation of more efficient, agile, and sustainable industrial systems. From our analysis, collaboration issues are at the heart of most challenges of this movement. Therefore, an analysis of collaboration needs to be made at all dimensions of Industry 4.0 vision, complemented with a mapping of these needs to the existing results from the collaborative networks area. In addition to such mapping, some new research challenges for the collaborative networks community, as induced by Industry 4.0, are also identified.
\end{abstract}

Keywords: Industry 4.0, Collaborative Networks, Smart Manufacturing.

\section{Introduction}

The idea of a $4^{\text {th }}$ industrial revolution, represented by terms such as Industry 4.0 and Smart Manufacturing, has attracted considerable attention namely as a result of a proposal by the German government and other initiatives from USA, Korea, and other countries [1], [2]. The initial notion primarily pointed to a merging of the physical and virtual worlds - cyber-physical system (CPS) - thus leading to a CPS-based industry. Soon the idea evolved to a symbiosis of CPS with Internet of Things and Internet of Services, justifying the view that it represents an evolution towards digitalization. This idea was then combined with the notion of "smartness" (intelligence dimension) reflected in terms such as smart factory, smart sensors, smart machines, smart products, smart environments, etc. [3]. This move therefore represents a symbiosis among the informatics, and particularly artificial intelligence, engineering, and manufacturing.

More recently, Industry 4.0 has turned into a buzzword [4] and became a catalyzer or "integration factor" for various new technologies and manufacturing concepts following the "me too" effect. As a result, its scope has increased - a kind of "everything fits" - making this concept even more difficult to grasp, while every technology-related company also tries to give this concept its own description. 
Nevertheless, this trend has brought a number of benefits, namely by creating a momentum to drive industrial transformation and upgrading, catalyzing multidisciplinary contributions, and promoting discussions and identification of new directions and possibilities, as clearly shown by the recent boom of business and academic publications related to Industry 4.0. Furthermore it has also created opportunities for attracting new political and financial support. In fact many countries have been launching local programs on Industry 4.0.

But there is also some risk associated with this new emergence. As usual, the hype creates excessive expectations, and overlooking several hard problems. Many newcomers look at it from a narrow perspective - the perspective of their own field of interest - with a potential loss of the vision and focus. Some publications and talks in conferences resemble the past discussions around the CIM (Computer Integrated Manufacturing) concept of the 1980s, just revamped with some new technologies.

From our perspective, in order to properly understand the vision of Industry 4.0 one needs to look at it from the lens of collaborative networks (CN). It might of course be argued that this is "yet another partial view". Nevertheless, since the collaborative networks area is by nature multi-disciplinary and interdisciplinary, it can enhance getting a more holistic understanding of the issues at stake here. We therefore claim that "collaboration" is at the heart of most challenges in Industry 4.0, and thus the area of Collaborative Networks shall be considered as a major enabler although certainly not the only one - for this industrial transformation. In fact, some important keywords for Industry 4.0 include "networking", "value chains", "vertical and horizontal integration", and "co-engineering / through engineering", which very well match the issues addressed for the CNs [1], [5]. A recent survey [8] also shows that "interconnection" and "collaboration" are two of the main clusters of terms found in related literature. As such, this work proposes an analysis of the relevant dimensions of Industry 4.0, while identifying their collaboration-related aspects and mapping them into the potential contributions from the $\mathrm{CN}$ area. Complementarily, a number of open issues are identified as research challenges with a more "collaborative" flavor of those concept, towards what we could term Collaborative Industry 4.0.

\section{Trends and Concepts}

\subsection{Industry 4.0 Concept Overview}

Industry 4.0 is mainly characterized by an increasing digitalization and interconnection of manufacturing systems, products, value chains, and business models. The interconnection between the physical and the virtual / cyber worlds Cyber-Physical Systems and Internet of Things - is a central feature.

In the literature, this concept is often described in terms of its four main dimensions or characteristics, namely: (1) vertical integration / networking, (2) horizontal integration / networking, (3) through-engineering, and (4) acceleration of manufacturing [1], [6]. Some authors also highlight two additional aspects: (5) 
digitalization of products and services, and (6) new business models and customer access or involvement [7]. Table 1 summarizes these dimensions.

Table 1 - Summary of characteristics of Industry 4.0

\begin{tabular}{|c|c|c|c|c|}
\hline & Characteristic & Notion & \multicolumn{2}{|c|}{ Some relevant topics } \\
\hline 1 & $\begin{array}{l}\quad \text { Vertical } \\
\text { integration or } \\
\text { networking of } \\
\quad \text { smart } \\
\text { production } \\
\text { systems }\end{array}$ & $\begin{array}{l}\text { Focuses on integrating processes } \\
\text { vertically across the entire } \\
\text { organization, via networking of } \\
\text { smart production systems, smart } \\
\text { products and smart logistics. [1], } \\
{[6],[8] \text {. }}\end{array}$ & $\begin{array}{l}\text { - Extensive CPS } \\
\text { - Interoperability } \\
\text { - Decentralization } \\
\text { - Virtualization } \\
\text { - Real-time availability } \\
\text { of data } \\
\text { - Service orientation }\end{array}$ & $\begin{array}{l}\text { - Modularization } \\
\text { - Enterprise wide data } \\
\text { analytics \& } \\
\text { Augmented reality } \\
\text { support } \\
\text { - Needs-oriented \& } \\
\quad \text { Individualized } \\
\text { - Optimization }\end{array}$ \\
\hline 2 & $\begin{array}{c}\text { Horizontal } \\
\text { integration } \\
\text { through global } \\
\text { value chain } \\
\text { networks }\end{array}$ & $\begin{array}{l}\text { Involves networking along the } \\
\text { whole value chain, from } \\
\text { suppliers and business partners to } \\
\text { customers [8], [1], "in order to } \\
\text { achieve seamless cooperation } \\
\text { between enterprises" [5], [9]. }\end{array}$ & $\begin{array}{l}\text { - Collaboration } \\
\text { - Transparency } \\
\text { - Interoperability } \\
\text { - Decentralization } \\
\text { - Data sharing } \\
\text { - Business ecosystem / } \\
\text { business community } \\
\text { - Track and tracing } \\
\end{array}$ & $\begin{array}{l}\text { - Safety \& security } \\
\text { - Global optimization } \\
\text { - Global flexibility } \\
\text { - Suppliers } \\
\text { orchestration } \\
\text { - Resilience } \\
\text { - Regulatory } \\
\text { framework } \\
\end{array}$ \\
\hline 3 & $\begin{array}{l}\text { Through- } \\
\text { engineering } \\
\text { across the } \\
\text { entire value } \\
\text { chain }\end{array}$ & $\begin{array}{l}\text { Integrates all engineering } \\
\text { activities considering the } \\
\text { complete life-cycle of the } \\
\text { product, from design / } \\
\text { production to retirement / } \\
\text { recycling [1], [6]. }\end{array}$ & $\begin{array}{l}\text { - Product life-cycle } \\
\text { - Co-engineering } \\
\text { - End-to-end } \\
\text { integration } \\
\text { - Circular economy } \\
\text { - Connecting \& } \\
\text { integrating } \\
\text { customers }\end{array}$ & $\begin{array}{l}\text { - Availability of data } \\
\text { at all stages } \\
\text { - Tracking \& tracing } \\
\text { - Service-enhance } \\
\text { products } \\
\text { - Creating new } \\
\text { product-service } \\
\text { offerings }\end{array}$ \\
\hline 4 & $\begin{array}{c}\begin{array}{c}\text { Acceleration } \\
\text { of } \\
\text { manufacturing }\end{array} \\
\end{array}$ & $\begin{array}{l}\text { Strive to optimize the whole } \\
\text { value chain through the so-called } \\
\text { "exponential technologies" (i.e. } \\
\text { exponentially growing } \\
\text { technologies), accelerating and } \\
\text { making industrial processes more } \\
\text { flexible [1], [6]. }\end{array}$ & $\begin{array}{l}\text { - IoT, CPS } \\
\text { - Mobile computing } \\
\text { - Robotics and drones } \\
\text { - Artificial Intelligence } \\
\text { - } \text { Additive } \\
\text { manufacturing } \\
\text { - Industrial biology }\end{array}$ & $\begin{array}{l}\text { - Neuro-technologies } \\
\text { - Nanotechnologies } \\
\text { - Sensing technologies } \\
\text { - Cloud, big data \& } \\
\quad \text { analytics } \\
\text { - Collaborative } \\
\quad \text { machines }\end{array}$ \\
\hline 5 & $\begin{array}{l}\text { Digitalization } \\
\text { of products } \\
\text { and services }\end{array}$ & $\begin{array}{l}\text { Moves to smart products, by } \\
\text { adding sensors, computing and } \\
\text { communication capabilities to } \\
\text { products, providing availability } \\
\text { of product data along its life- } \\
\text { cycle, introducing new digital } \\
\text { products, and associating } \\
\text { business services to products [7]. }\end{array}$ & $\begin{array}{l}\text { - Self-identification } \\
\text { - History record and } \\
\text { tracing } \\
\text { - Augmented reality } \\
\text { - Data availability }\end{array}$ & $\begin{array}{l}\text { - Service-enhanced } \\
\text { products } \\
\text { - Assistance } \\
\text { - Self-diagnosis, self- } \\
\text { configuration }\end{array}$ \\
\hline 6 & $\begin{array}{l}\text { New business } \\
\text { models and } \\
\text { customer } \\
\text { access }\end{array}$ & $\begin{array}{l}\text { Focuses on new business models } \\
\text { that take advantage on } \\
\text { digitalization and networking in } \\
\text { data-rich contexts, along the } \\
\text { value chain. Such models will } \\
\text { deepen digital relationships with } \\
\text { more empowered customers, and } \\
\text { accelerate globalization but with } \\
\text { distinct local/regional flavors [7]. }\end{array}$ & $\begin{array}{l}\text { - Customer experience } \\
\text { - Customer intimacy } \\
\text { - Co-design / co- } \\
\text { creation } \\
\text { - Value chain } \\
\text { - Link to smart } \\
\text { infrastructures }\end{array}$ & $\begin{array}{l}\text { - Product-service } \\
\quad \text { ecosystem } \\
\text { - Sustainability } \\
\text { - Social responsibility } \\
\text { - Glocal enterprise }\end{array}$ \\
\hline
\end{tabular}


This industrial transformation momentum towards industry 4.0 is driven by two major forces - the new technological possibilities, and the fast changing market demands (Fig. 1).

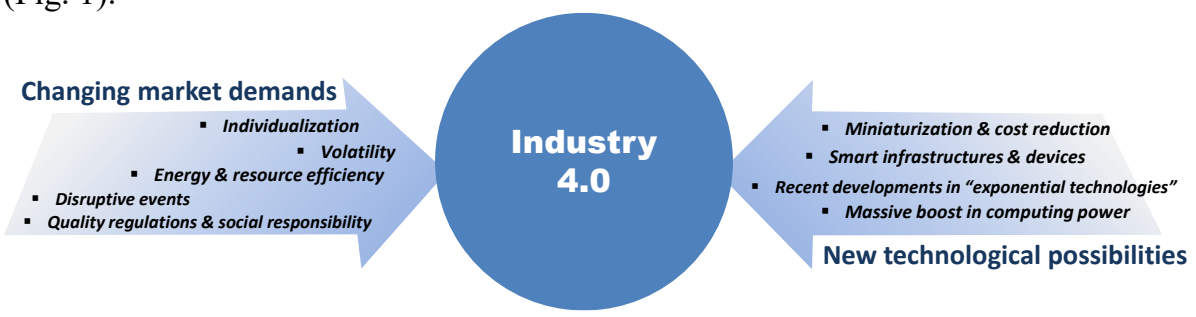

Fig. 1 - Driving forces

From a technological perspective, Industry 4.0 is in fact characterized by the combination of large variety of enabling technologies [10], [11]. Furthermore, the role of data - available in fast growing amounts - is becoming central not only challenging the re-design of past systems and solutions, but also motivating new services and products.

\subsection{Collaborative Networks Overview}

The area of CNs is nowadays represented by a large literature basis [12], [13] and a great variety of implementations, corresponding to multiple classes of collaborative networks. To support this variety of collaboration forms, a large number of models, infrastructures, mechanisms and tools have been developed, as summarized in Fig. 2.
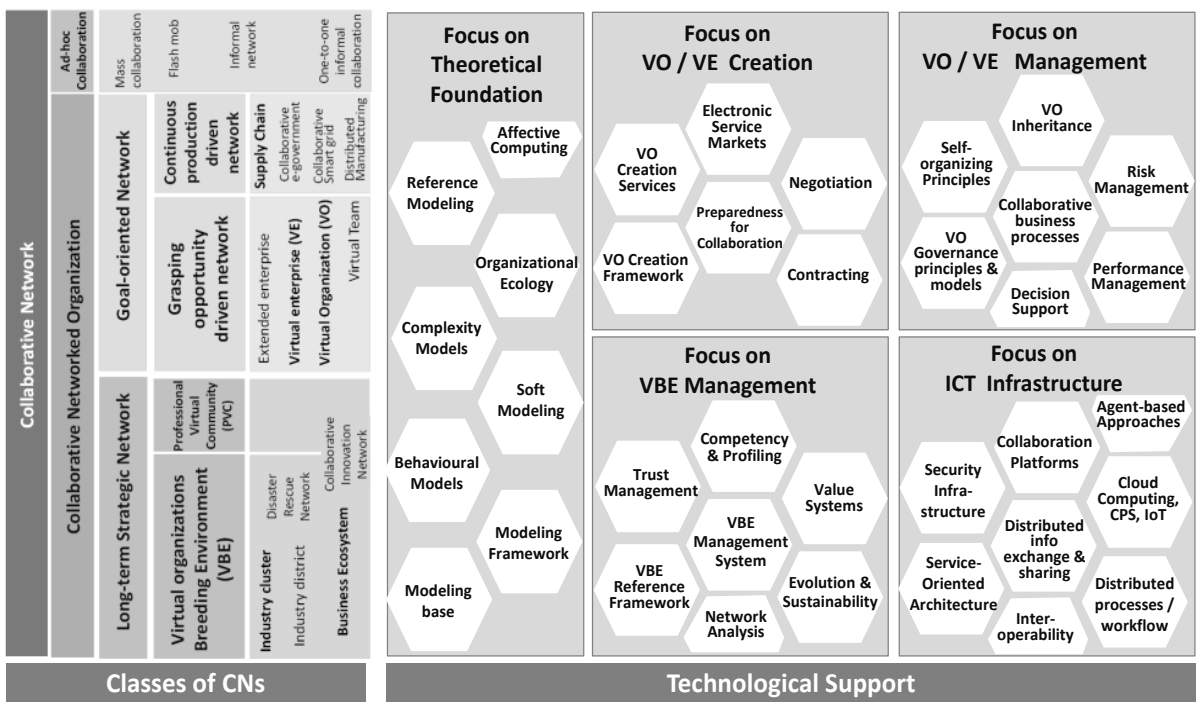

Fig. 2 - Collaborative Networks and some of their supporting technologies

Many of these developments have been directed to manufacturing and other industrial applications, which make the area a natural contributor to Industry 4.0. 


\section{Collaboration Issues in Industry 4.0}

Numerous collaboration issues emerge from the characteristics of Industry 4.0, as summarized in the following Tables 2 to 7 . As illustrated in Fig. 3, a good number of contributions to solve these issues can be found in the research on CNs. These examples, although not a complete list, clearly show the relevance of CNs for the materialization of this industrial revolution. On the other hand, further research areas can also be identified, as presented in Section 4.

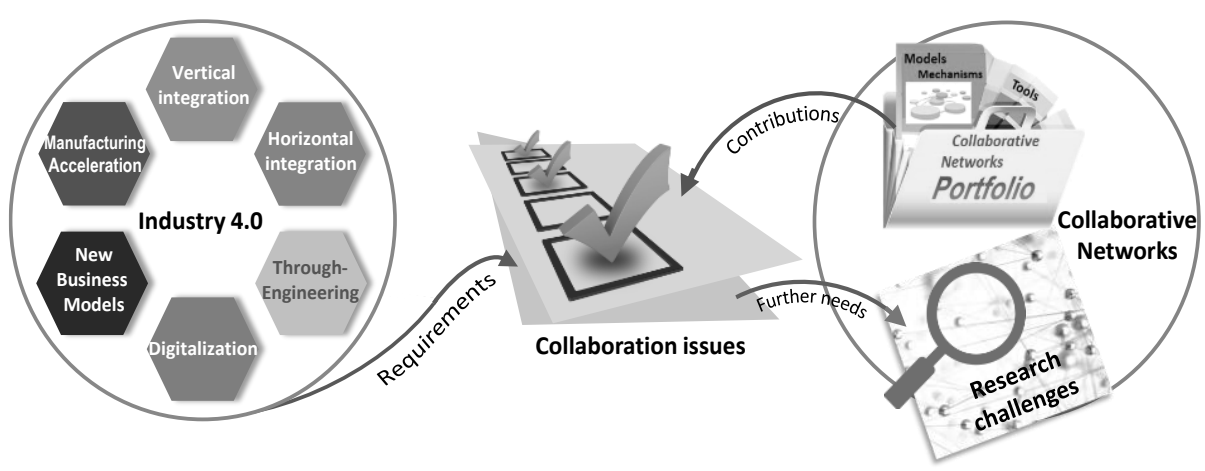

Fig. 3. Mapping Industry 4.0 into Collaborative Networks

Table 2. Collaboration issues in vertical integration of smart production systems

Examples of collaboration-related issues
With the increase of intelligence and autonomy of - With the increase of intelligence and autonomy of
enterprise systems, vertical integration more and more corresponds to networking of smart systems, which need to collaborate in order to support agile processes. For instance, at shop floor this leads to a move from "control structures" to "collaborative structures" (from CPS and embedded systems to collaborative CPS).

- Collaboration between humans and robots is an emerging field, often limited to one-to-one model, but that can be enlarged to a network level.

- Future enterprises can be seen as multi-layer networks, involving the interplay of smart production systems, smart products, smart logistics, organizational units, and people. Support for real-time monitoring and agility requires fluid interplay among these multiple layers (up and downstream).

- Real-time availability of data and enterprise wide analytics and augmented reality supported data visualization can be better supported by a collaborative model among the various enterprise units.

\section{What $\mathrm{CN}$ can contribute}

- Although most $\mathrm{CN}$ research has focused on networks of organizations or networks of people, some earlier suggestions to apply the same concepts to networks of machines [14] and CPS [15] are available.

- Some works addressed the interplay among CNs [16].

- From the area of multi-agent systems and distributed artificial intelligence, models and protocols for collaboration among agents have been extensively discussed and applied to manufacturing [17].

- The concept of sensing, smart, and sustainable enterprise offers a comprehensive view of integration [18]. 
Table 3. Collaboration issues in horizontal integration through global value chain networks

\section{Examples of collaboration-related issues}

- Collaboration among all stakeholders along the value chain, including business partners and customers.

- Materialization of business ecosystems, which are strategic cooperative alliances.

- Sharing of resources and information along the value chain, one of the facets of collaboration.

- Global optimization, which requires a network-oriented perspective and not an enterprise-centric view.

- Global flexibility requires dynamic formation of goaloriented networks to adapt to changes.

- Resilience, thus the capability to absorb shocks and disruptions, requires collaboration with high level of sharing.

- Tracking and tracing functionalities require high level of transparency and sharing among the value chain.

- Some authors also explore the integration of smart manufacturing with smart cities [30].
What $\mathrm{CN}$ can contribute

- This is the area more extensively covered by $\mathrm{CN}$ research [12], [13], [q]. Extensive results are available on:

- Organizational models, including strategic alliances (e.g. VBEs, business ecosystems) and goal-oriented networks [19], [20].

- Collaboration platforms, tools and information management supporting needs of the various phases of the $\mathrm{CN}$ life-cycle [19], [21], [22].

- Governance and behavioural models [20], [23], [24].

- Trust management [25].

- Reference models [26], [27], [28].

- Resilience and CNs [29]

Table 4. Collaboration issues in through-engineering across the entire value chain

\section{\begin{tabular}{|l|l} 
Examples of collaboration-related issues & What $\mathrm{CN}$ can contribute
\end{tabular}}

- Involvement of customers in product design (co-design) as well as close interaction among engineers of different nodes along the value chain (co-engineering) require effective collaboration between manufacturers and customers, possibly involving intermediary stakeholders.

- Consideration of full-life cycle of product and circular economy requires collaboration among multiple stakeholders.

- Service-enhanced products or association of business services to products usually requires well-coordinated networks, involving manufacturers and service providers, namely for delivering integrated service packages. This is particularly critical when there is a need for differentiation according to geographical area.

Co-design, co-innovation and customer communities are topics addressed in various $\mathrm{CN}$ works, e.g. [31], [32].

- The interactions between the product life-cycle and the $\mathrm{CNs}$ life-cycle were studied in GloNet [23]

- The role of CNs in supporting service-enhanced products / product-service systems has been a major research topic in recent years [24], [33], [34], [35], [53].

Table 5. Collaboration issues in acceleration of manufacturing

\section{Examples of collaboration-related issues}

- Fast introduction of new technologies requires dynamic involvement of new players along the value chain, and thus agile collaborative structures.

- Some of the "exponential technologies" strongly based on AI more and more suggest collaboration among machines (M2M). This trend naturally involves issues such as sharing, interoperability, negotiation and contracting, and trust management, etc.

- Mobile technologies challenge the closed ecosystem models and require collaborative models that cope with nomadic systems.

\section{What $\mathrm{CN}$ can contribute}

- Combining results from the multiagent systems area [18] and from $\mathrm{CN}$ [36] regarding consortia formation can provide good support to agility.

- Till now 3D printing has been studied mostly from a technological point of view and only recently as a new enabler of new collaboration models [37]

- Virtual and augmented reality 
- Technologies such as 3D printing allow for distributed and localized manufacturing, involving collaboration among actors located in different geographical locations. - The increasing role of virtual and augmented reality as a tool to collaborate during training activities, to interact in an innovative way and for simulation and management of a certain situation can affect collaboration. have been studied as a tool for training and for management of processes, but only recent developments of mobile and connectivity concepts can change the way $\mathrm{CNs}$ are conceptualized (virtual and real participants) [http://vf-os.eu/ ]

The above tables are focused on the four main characteristics of Industry 4.0. The two other characteristics mentioned in Fig. 1, although partially overlapping the cases mentioned above, also require a strong collaborative networks component, as shown in Table 6 and Table 7.

Table 6. Collaboration issues in digitalization of products and services

\section{Examples of collaboration-related issues}

- Leveraging the notion of smart product can only be done through effective collaboration among nodes of the value chain, which use the smart product to mediate their collaboration (ako stigmergy); otherwise the full potential of the concept cannot be achieved.

- It is through collaboration that effective history records and tracing can be kept updated and associated to the product.

- Data availability next to the product depends on the technological infrastructure but also on the collaboration among all stakeholders involved in the "product history".

- Inclusion of assistance and other value-added services typically requires contributions from various stakeholders, which implies at least some minimal levels of collaboration - being the "smartness of the product" their common goal.

- Smart products will inspire / motivate the creation of new services to enhance the value of products, which opens the opportunity for new players, thus creating collaboration communities associated to the product (product-related digital ecosystems.

\section{What $\mathrm{CN}$ can contribute}

- Some examples of stigmergic collaboration can be found in mass collaboration in which "agents communicate with one another indirectly through traces left in the shared environment" [38]. A typical example is Wikipedia.

- Collaboration of multiple stakeholders in integrated business services provision has been addressed [33], [39], [40], including aspects such as valueadded / integrated service composition, service discovery in collaborative environments, etc.

- Role of CNs in transition to product-service systems [35], [41].

- Role of CNs in innovation ecosystems and open innovation [42], [43].

Table 7. Collaboration issues in new business models and customer access

\section{Examples of collaboration-related issues}

- This dimension further extends the "horizontal integration", seeking tight collaboration along the value chain.

- Collaboration with customers (co-design/co-creation of products and services), not necessarily under the one-toone model, but rather under a community perspective (increasing "customer intimacy"). Improving customer experience, namely in global markets, also requires close collaboration among value chain stakeholders.

- Addressing global markets taking into account local specificities (notion of global enterprise) requires

\section{What CN can contribute}

- Numerous forms of goal-oriented networks have been implemented in diverse industry sectors [44].

- The involvement of customer in co-creation networks has been studied in various sectors, e.g. solar energy [31], consumer goods sector [45], [21], etc.

- Materialization of the glocal enterprise concept through $\mathrm{CNs}$ [40]. 


\begin{tabular}{|c|c|}
\hline $\begin{array}{l}\text { collaboration between global producers and local } \\
\text { providers and other entities close to the customer. } \\
\text { - The move towards "servitization" more and more } \\
\text { requires tight collaboration between manufacturers and a } \\
\text { growing variety of service providers. } \\
\text { - Current concerns regarding sustainability and social } \\
\text { responsibility require stronger collaboration links } \\
\text { between industry and other societal actors. } \\
\text { - Hybrid value chains, combining for-profit and non-for- } \\
\text { profit organizations. }\end{array}$ & $\begin{array}{l}\text { - New models for collaboration in } \\
\text { Non-hierarchical value chains [22]. } \\
\text { - The role of CNs in product-service } \\
\text { systems / servitization [35], [41]. } \\
\text { - The role of CNs in sustainability } \\
\text { has been discussed in various } \\
\text { works, e.g. [46] [18] and even been } \\
\text { the main theme of the } 2010 \text { PRO- } \\
\text { VE edition [47]. } \\
\text { - Notions of green virtual enterprise } \\
\text { and green enterprise breeding } \\
\text { environment have been introduced } \\
\text { [48]. }\end{array}$ \\
\hline
\end{tabular}

\section{New Research Challenges}

Last decades of research in CNs resulted in a large base of theoretical and empirical knowledge, which provides a strong support to the collaboration requirements of Industry 4.0, as summarized in Section 3. Furthermore, the catalyzing "movement" originated with the Industry 4.0 concept is raising new challenges and pointing to areas requiring further research in CNs. Some of these areas include:

- Combination and interplay of multiple dynamic networks. The aimed vertical and horizontal integration dimensions and the need to support the various stages of the product life-cycle lead to the co-existence of multiple networks, formal and informal, involving organizations, people, systems, and machines. These networks have different durations and thus different life-cycles. Understanding the nature and supporting the interactions / interdependences among these networks is crucial for the effectiveness, agility, and resilience of future manufacturing systems. Although some inputs towards this aim can be found in [16], this issue remains an important research challenge.

- Coping with and benefiting from data-rich environments. The increasing availability and use of sensors and smart devices, integrated as cyber-physical systems, combined with the hyper-connection of organizations, people, and systems, generate fast increasing amounts of data. These emerging data-rich environments challenge $\mathrm{CNs}$ and associated decision-making systems. Previous design assumptions, based on scarcity of data, need to be revisited, probably leading to new architectures and mechanisms. Furthermore, new collaborative business services that leverage the value of big data are likely to emerge. On the other hand, data-richness also raises issues regarding data validity and quality, data protection, access, and ownership.

- Extend the use of a CNs perspective to complex CPS. Earlier CPS/IoT efforts were focused on the base technological aspects, such as interconnectivity, safe communications, control, and coping with limited energy and computing resources. As the level of intelligence, and thus the autonomy, of devices, machines and systems increases, and the number of interconnected entities grows exponentially, it is necessary to bring in new perspectives in terms of 
organizational structures (e.g. communities or ecosystems of smart entities), and moving from a "control-orientation" towards a collaboration perspective.

- Extend the idea of collaborative networks to communities of machines and H-M collaboration. Taking advantage of new interfacing technologies, e.g. natural user interfaces, augmented and virtual reality, holograms, more effective approaches for human-machine collaboration can be developed. The emerging field of "collaborative robotics" points in this direction, but instead of a one-to-one collaboration model (as in current systems) [49], a more comprehensive networked model can be envisioned. In other words, new H-M interfacing technologies allow to revisit the concept of balanced automation systems [50], [51], re-enforcing the collaboration perspective (human-enhancement and humanmachine symbiosis).

- Networks involving hybrid value systems. The need to properly consider the societal dimension and systems sustainability require an increasing collaboration of manufacturing industries with other societal stakeholders. Thus a collaboration among public, NGOs, and private entities, guided by different value systems, which calls for a better understanding of the interactions and alignment of value systems in CNs. Furthermore smart cities, smart communities need to include and to consider the role of manufacturing companies for the wealth of the country.

- Further develop the sensing, smartness, and sustainability dimensions. New products, processes, enterprises, communities, and infrastructures need to be envisioned as sensing, smart and sustainable (S3), extending the concept of "S3 enterprise" [52], in order to transcend individual interests and better satisfy collective aspirations. Human capability and machine intelligence need to be integrated within production systems so to achieve maximum efficiency as well as worker satisfaction. Research efforts should tackle social sustainability challenges at all levels of manufacturing industries (from shop-floor to production systems to networks).This implies moving from an enterprise-centric perspective to a business ecosystem-oriented perspective. $\mathrm{CNs}$ is a key enabler for the materialization of this idea, which requires the integration and interaction of multiple entities that are heterogeneous, distributed and autonomous, but that must collaborate in order to achieve their collective goals.

- Seek inspiration in nature, towards optimized solutions. Nature is full of examples of successful collaboration processes, shown in a wide variety of forms, and which seem to be highly optimized. On the other hand, seeking optimized, agile and sustainable solutions is a core goal of Smart Manufacturing. Therefore, a study of research results from Nature-related disciplines regarding collaboration can provide good inspiration to better understand and replicate sustainable collaboration mechanisms and organizational structures.

- Deployment of open linked data and interlinking of open ontologies to enhance collaboration among autonomous and heterogeneous connected agents in collaborative environments. This is crucial to support both vertical and horizontal integration. 
- Better service specification mechanism, enhancing service discovery, composition and evolution in collaborative environments, coping with mobility and evolution of manufacturing equipment.

- Further develop monitoring and supervision of agents collaboration in coopetitive environments. This requires further development of behavioral models, and other advanced aspects such as collective emotions, resilience mechanisms and antifragility in order to cope with disruptive events, etc.

- New business models for new CNs: upon the changes enabled by Industry 4.0 the structure, the actors, the interaction mechanisms, the value creation mechanisms of CNs will change. Organizations (both public and private) will be asked to revise their processes, rules of collaboration, as well as regulatory systems. In the specific case of manufacturing companies, service orientation, inclusion of sustainability issues, availability of big data, etc., are strategies that need to be accompanied by new organizational models.

- Re-enforce interdisciplinary work. The increasing levels of integration envisioned by Industry 4.0 clearly require the contribution from multiple disciplines. The CNs area, the result of an interdisciplinary effort in itself, can facilitate the needed dialog among all stakeholders in Industry 4.0, but also needs to be continuously re-enforced, seeking synergies among multiple knowledge areas.

- Further education and dissemination of CN concepts in industry. Performing this industrial revolution is not only a matter of technology. It requires a different mind-set, new ways of working, a new culture. For this to happen, and considering the enabling role of collaborative networks, it is necessary to invest further on education and dissemination of $\mathrm{CN}$ concepts in the industrial communities.

\section{Conclusions}

The vision behind Industry 4.0 and alternative terms such as Smart Manufacturing is having a strong catalyzing effect, reflected in the convergence of various new technologies and mobilization of efforts towards reorganization of industry. To some authors this effect is triggering a new industrial revolution.

An effective materialization of this vision strongly relies, in our opinion, on collaborative organizational structures, processes, and mechanisms. This position is confirmed through an analysis of the Industry 4.0 requirements along its six dimensions - vertical integration, horizontal integration, through-engineering, acceleration of manufacturing, digitalization, and new business models - which allowed us to identify a large number of collaboration-related issues.

From an analysis of literature on collaborative networks, a great number of research results and empirical knowledge gathered along the last two decades which constitute a rich contribution to the identified needs, positioning CNs as a major enabler of Industry 4.0.

Complementarily, this analysis shows that this revolution also raises new research challenges or re-enforces ongoing focus topics in the $\mathrm{CN}$ community. A preliminary 
list of examples of such challenges was elaborated, although further refinement is needed.

Acknowledgments. This work was partially funded by the FCT- Strategic program UID/EEA/00066/2013 (Impactor project) and Socolnet (ARCON-ACM project).

\section{References}

1. Gilchrist, A.: Industry 4.0 - The Industrial Internet of Things. Apress, Bangken, Nonthaburi, Thailand. DOI 10.1007/978-1-4842-2047-4 (2016).

2. Bartodziej, C. J.: The Concept Industry 4.0 - An Empirical Analysis of Technologies and Applications in Production Logistics. Springer Gabler, Wiesbaden, Germany. DOI 10.1007/978-3-658-16502-4 (2017).

3. Kang, H.S., Lee, J.Y., Choi, S. Kim, H., Park, J. H., Son, J. Y., Kim, B. H., Noh, S. D.: Smart manufacturing: Past research, present findings, and future directions. Int. J. of Precis. Eng. and Manuf.-Green Tech. 3(1): 111-128. (2016)

4. Drath, R., Horch, A.: Industrie 4.0: Hit or Hype? [Industry Forum]. In: IEEE Industrial Electronics Magazine, vol. 8, no. 2, pp. 56-58. DOI: 10.1109/MIE.2014.2312079 (2014)

5. Sniderman, B., Mahto, M., Cotteleer, M. J.: Industry 4.0 and manufacturing ecosystems Exploring the world of connected enterprises. Deloitte University Press (accessed 9 Mar 2017) https://dupress.deloitte.com/content/dam/dup-us-en/articles/manufacturingecosystems-exploring-world-connectedenterprises/DUP_2898_Industry4.0ManufacturingEcosystems.pdf (2016).

6. Schlaepfer, R. C., Koch, M., Merkofer, P.: Industry 4.0 - Challenges and solutions for the digital transformations and use of exponential technologies. Deloitte, Zurich (accessed 9 Mar 2017) http://www.industrie2025.ch/fileadmin/user_upload/ch-en-delloite-ndustry-4-024102014.pdf (2015).

7. Geissbauer, R., Vedso, J., Schrauf, S.: Industry 4.0: Building the digital enterprise. PwC (accessed 9 Mar 2017) https://www.pwc.com/gx/en/industries/industries-4.0/landingpage/industry-4.0-building-your-digital-enterprise-april-2016.pdf (2016).

8. Hermann, M., Pentek, T., Otto, B.: Design Principles for Industrie 4.0 Scenarios. In: 2016 49th Hawaii International Conference on System Sciences (HICSS), Koloa, HI, 2016, IEEE Xplore, pp. 3928-3937. DOI: 10.1109/HICSS.2016.488 (2016).

9. Zhou, K., Liu, T., Zhou, L.: Industry 4.0: Towards Future Industrial - Opportunities and Challenges. In: 2015 12th International Conference on Fuzzy Systems and Knowledge Discovery (FSKD), Zhangjiajie, pp. 2147-2152. DOI: 10.1109/FSKD.2015.7382284 (2015).

10. MTC: From Industry 4.0 to Digitising Manufacturing - An End User Perspective. Conference Report, Manufacturing Technology Center, Coventry (accessed 9 Mar 2017) http://www.the-mtc.org/pdf/Industry-4-Report-2016-e.pdf (2016)

11. Wan, J., Cai, H., Zhou, K.: Industrie 4.0: Enabling Technologies. In: 2015 International Conference on Intelligent Computing and Internet of Things (IC1T), Harbin, China, 2015, pp. 135-140. IEEE Xplore. DOI: 10.1109/ICAIOT.2015.7111555 (2015).

12. Durugbo, C.: Collaborative networks: a systematic review and multi-level framework. International Journal of Production Research, 54(12): 3749-3776 (2016). 
13. Appio, F. P., Martini, A., Massa, S., Testa, S.: Collaborative network of firms: antecedents and state-of-the-art properties. International Journal of Production Research, in press, DOI: 10.1080/00207543.2016.1262083 (2017).

14. Barata, J., Camarinha-Matos, L. M.: Coalitions of manufacturing components for shopfloor agility. Int. Journal of Networking and Virtual Organizations, 2(1): 50-77 (2003).

15. Nazarenko, A., Camarinha-Matos, L. M.: Towards Collaborative Cyber-Physical Systems. Proceedings of YEF-ECE 2017 - Young Engineers Forum on Electrical and Computer Engineering, Costa de Caparica, Portugal, 5 May 2017, pp. 12-17. IEEE Xplore. (2017).

16. Camarinha-Matos, L.M., Ferrada, F., Oliveira, A. I.: Interplay of Collaborative Networks in Product Servicing, In: Collaborative Systems for Reindustrialization, Springer, IFIP Series 408/2013, pp. 51-60 (2013).

17. Shen, W., Norrie, D. H., Barthès, J.-P.: Multi-Agent Systems for Concurrent Intelligent Design and Manufacturing. Taylor \& Francis: London, New York (2003).

18. Weichhart, G., Molina, A., Chen, D., Whitman, L. E., Vernadat, F.: Challenges and current developments for Sensing, Smart and Sustainable Enterprise Systems. Computers in Industry, 79: 34-46 (2016).

19. Camarinha-Matos, L. M., Afsarmanesh, H., Galeano, N., Molina, A.: Collaborative networked organizations-Concepts and practice in manufacturing enterprises. Computers \& Industrial Engineering, 57(1): 46-60 (2009).

20. Shadi, M., Afsarmanesh, H.: Behavioral Norms in Virtual Organizations. In: Collaborative Systems for Smart Networked Environments, IFIP AICT series 434, Springer, pp 48-59 (2014).

21. Shamsuzzoha A., Kankaanpaa T., Carneiro L.M., Almeida R., Chiodi A. \& Fornasiero R.: Dynamic and collaborative business networks in the fashion industry. International Journal of Computer Integrated Manufacturing, 26(1-2): 125-139 (2013).

22. Almeida R., Carneiro L.M., Sà A., Ferreira P.S., Fornasiero R.: Business Communities Management. In: Intelligent Non-hierarchical Manufacturing Networks, Wiley ISBN: 978184821481, (2012)

23. Camarinha-Matos, L. M., Oliveira, A. I., Ferrada, F., Sobotka, P., Vataščinová, A., Thamburaj, V.: Collaborative enterprise networks for solar energy. 2015 International Conference on Computing and Communications Technologies (ICCCT), Chennai, 2015, pp. 93-98. doi: 10.1109/ICCCT2.2015.7292726 (2015).

24. Camarinha-Matos, L. M., Ferrada, F., Oliveira, A. I., Afsarmanesh, H.: Supporting productservicing networks, Proceedings of 2013 International Conference on Industrial Engineering and Systems Management (IESM), Rabat, 2013, pp. 1-7 (2013).

25. Msanjila, S., Afsarmanesh, H.: Trust analysis and assessment in virtual organization breeding environments. International Journal of Production Research, 46: 1253-1295 (2008).

26. Camarinha-Matos, L. M., Afsarmanesh, H.: On reference models for collaborative networked organizations. International Journal Production Research, 46(9): 2453 - 2469 (2008).

27. Carneiro, L., Shamsuzzoha, A. H. M., Almeida, R., Azevedo, A., Fornasiero, R., \& Ferreira, P. S.: Reference model for collaborative manufacturing of customised products: applications in the fashion industry. Production Planning \& Control, 25(13-14): 11351155. (2014).

28. Fornasiero, R., Zangiacomi, A., Franchini, V., Bastos, J., Azevedo, A., \& Vinelli, A.: Implementation of customisation strategies in collaborative networks through an innovative Reference Framework. Production Planning \& Control, 14: 1158-1170 (2016).

29. Camarinha-Matos, L. M.: Collaborative Networks: A Mechanism for Enterprise Agility and Resilience. In: Enterprise Interoperability VI (K. Maertins et al. Eds.), Proceedings of the IESA 7, Springer, pp. 3-11 (2014). 
30. Lom, M., Pribyl, O., Svitek, M.: Industry 4.0 as a part of smart cities. In: 2016 Smart Cities Symposium Prague (SCSP), Prague, IEEE Xplore, pp. 1-6. DOI: 10.1109/SCSP.2016.7501015 (2016).

31. Oliveira, A. I., Camarinha-Matos, L. M.: Negotiation Support for Co-Design of Business Services. In: Collaborative Systems for Smart Networked Environments, IFIP Series 434/2014, pp 98-106, Springer (2014).

32. Romero, D., Molina, A.: Collaborative networked organisations and customer communities: value co-creation and co-innovation in the networking era. Production Planning \& Control, 22(5-6): 447-472 (2011).

33. Afsarmanesh, H. Shafahi M., Sargolzaei, M.: On service-enhanced product recommendation guiding users through complex product specification. International Conference on Computing and Communications Technologies (ICCCT), Chennai, 2015, pp. 43-48. doi: 10.1109/ICCCT2.2015.7292717 (2015)

34. Bertoni, A., Bertoni, M., Panarotto, M., Johansson, C., Larsson, T. C.: Value-driven product service systems development: Methods and industrial applications. CIRP Journal of Manufacturing Science and Technology, 15: 42-55 (2016).

35. Boucher, X.: Economic and Organizational Transition towards Product/Service Systems: The Case of French SMEs. In: Collaborative Networks in the Internet of Services, IFIP AICT series 380, Springer, pp 26-34 (2012).

36. Oliveira, A. I., Camarinha-Matos, L. M., Pouly, M.: Agreement negotiation support in VO creation - an illustrative case. Journal of Production Planning and Control, 21(2): 160-180 (2010).

37. Janssen R., Blankers I., Moolenburgh E., Posthumus B.: The Impact of 3-D Printing on Supply Chain Management White paper by TNO http://publications.tno.nl/publication/34610218/0zCfLz/janssen-2014-impact.pdf (accessed 3 Apr 2017). (2014).

38. Elliot, M.: Stigmergic Collaboration: A Framework for Understanding and Designing Mass Collaboration. In: Mass Collaboration and Education, Computer-Supported Collaborative Learning Series, 16: 65-84, Springer. (2016).

39. Camarinha-Matos, L. M., Afsarmanesh, H., Oliveira, A. I., Ferrada, F.: Cloud-based Collaborative Business Services Provision, in Enterprise Information Systems, Lecture Notes on Business Information Processing, Volume 190, pp 366-384, Springer (2014).

40. Camarinha-Matos, L. M., Afsarmanesh, H., Koelmel, B.: Collaborative Networks in Support of Service-Enhanced Products. In: Adaptation and Value Creating Collaborative Networks, IFIP AICT Series 362/2011, Springer, pp. 95-104 (2011).

41. Peillon, S., Dahmani, S., Boucher, X.: A Formal Model-Based Approach to Engineering Systems-of-Systems. In: Collaborative Networks in the Internet of Services, IFIP AICT series 380, Springer, pp 35-42 (2012).

42. Durugbo, C., Lyons, A.: Collaboration for Innovation Networks: Towards a Reference Model. In: Risks and Resilience of Collaborative Networks, IFIP AICT series 463, Springer, pp 311-322 (2015).

43. Rabelo, R. J., Bernus, P., Romero, D.: Innovation Ecosystems: A Collaborative Networks Perspective. In: Risks and Resilience of Collaborative Networks, IFIP AICT series 463, Springer, pp 323-336 (2015).

44. Romero, D., Rabelo, R. J., Molina, A.: Collaborative Networks as Modern Industrial Organisations: Real Case Studies. International Journal of Computer Integrated Manufacturing, 26(1-2): 1-2 (2013).

45. Fornasiero R., Zangiacomi A.: A structured approach for customised production in SME collaborative networks. International Journal of Production Research, 51(7): 2110-2122 (2013). 
46. Camarinha-Matos, L.M., Afsarmanesh, H., Boucher, X.: The Role of Collaborative Networks in Sustainability. In: Collaborative Networks for a Sustainable World, IFIP AICT Series 336/2010, Springer, pp. 1-16 (2010).

47. Camarinha-Matos, L.M., Boucher, X., Afsarmanesh, H.: Collaborative Networks for a Sustainable World. IFIP AICT Series 336, Springer (2010).

48. Romero, D., Noran, O., Afsarmanesh, H.: Green Virtual Enterprise Breeding Environments Bag of Assets Management: A Contribution to the Sharing Economy. In: Risks and Resilience of Collaborative Networks, IFIP AICT series 463, Springer, pp 439-447 (2015).

49. Moniz, A. B., Krings, B.-J.: Robots Working with Humans or Humans Working with Robots? Searching for Social Dimensions in New Human-Robot Interaction in Industry. Societies, 6(3): 23. (2016).

50. Camarinha-Matos, L. M., Rabelo, R., Osório, A. L.: Balanced Automation. In: Computer Assisted Management and Control of Manufacturing Systems, Springer-Verlag, London, pp. 376-414 (1997).

51. Romero, D., Noran, O., Stahre, J., Bernus, P., Fast-Berglund, A.: Towards a HumanCentred Reference Architecture for Next Generation Balanced Automation Systems: Human-Automation Symbiosis. In: Advances in Production Management Systems: Innovative Production Management Towards Sustainable Growth, Part II, AICT 460, Springer, 556-566 (2016)

52. Weichhart, G., Molina, A., Chen, D., Whitman, L. E. and Vernadat, F.: Challenges and current developments for Sensing, Smart and Sustainable Enterprise Systems. Computers in Industry, 79: 34-46 (2016).

53. Afsarmanesh, H., Sargolzaei, M. and Shadi, M.: Semi-automated software service integration in virtual organisations. Enterprise Information Systems, 9(5-6), pp.528-555 (2015). 